\title{
Atmospheric Deposition and Ozone Levels in Swiss Forests: Are Critical Values Exceeded?
}

\author{
Peter Waldner - Marcus Schaub • Elisabeth Graf Pannatier • \\ Maria Schmitt • Anne Thimonier • Lorenz Walthert
}

Received: 3 February 2006 / Revised: 19 June 2006 / Accepted: 20 June 2006 / Published online: 23 January 2007

(C) Springer Science + Business Media B.V. 2007

\begin{abstract}
Air pollution affects forest health through atmospheric deposition of acidic and nitrogen compounds and elevated levels of tropospheric ozone $\left(\mathrm{O}_{3}\right)$. In 1985, a monitoring network was established across Europe and various research efforts have since been undertaken to define critical values. We measured atmospheric deposition of acidity and nitrogen as well as ambient levels of $\mathrm{O}_{3}$ on 12, 13, and 14 plots, respectively, in the framework of the Swiss Long-Term Forest Ecosystem Research (LWF) in the period from 1995 to 2002 . We estimated the critical loads of acidity and of nitrogen, using the steady state mass balance approach, and calculated the critical $\mathrm{O}_{3}$ levels using the AOT40 approach. The deposition of acidity exceeded the critical loads on 2 plots and almost reached them on 4 plots. The median of the measured molar ratio of base nutrient cations to total dissolved aluminium $(\mathrm{Bc} / \mathrm{Al})$ in the soil solution was higher than the critical value of 1 for all depths, and also at the plots with an exceedance of the critical load of acidity. For nitrogen, critical loads were exceeded on 8 plots and deposition likely represents a long-term ecological risk on 3 to 10 plots. For $\mathrm{O}_{3}$,
\end{abstract}

P. Waldner $(\bowtie) \cdot$ M. Schaub $\cdot$ E. Graf Pannatier .

M. Schmitt $\cdot$ A. Thimonier $\cdot$ L. Walthert

WSL, Swiss Federal Institute for Forest,

Snow and Landscape Research,

Zürcherstrasse 111,

8903 Birmensdorf, Switzerland

e-mail: peter.waldner@wsl.ch exceedance of critical levels was recorded on 12 plots, and led to the development of typical $\mathrm{O}_{3}$-induced visible injury on trees and shrubs, but not for all plots due to (1) the site specific composition of $\mathrm{O}_{3}$ sensitive and tolerant plant species, and (2) the influence of microclimatic site conditions on the stomatal behaviour, i.e., $\mathrm{O}_{3}$ uptake.

Keywords acid deposition $\cdot$ critical levels $\cdot$ critical loads · forest · ICP-Forests Level II · LWF · nitrogen · risk assessment $\cdot$ tropospheric ozone $\cdot$ Switzerland

\section{Introduction}

The release of pollutants such as sulphur dioxide $\left(\mathrm{SO}_{2}\right)$, nitrogen oxides $\left(\mathrm{NO}_{\mathrm{x}}\right)$ and ammonia $\left(\mathrm{NH}_{3}\right)$ into the atmosphere has increased massively during the last century, raising concerns about the effects of resulting changes in atmospheric deposition and ambient air concentrations on forest ecosystems in Central Europe and elsewhere (Percy and Ferretti 2004).

In Switzerland, the concentrations of $\mathrm{SO}_{2}, \mathrm{NO}_{\mathrm{x}}$ and $\mathrm{NH}_{3}$ increased significantly between 1950 and 1990 . Since the 1990s, $\mathrm{SO}_{2}$ concentrations have been reduced to pre-1950 levels through the implementation of various measures. Although $\mathrm{NO}_{\mathrm{x}}$ and $\mathrm{NH}_{3}$ were also reduced, the target concentrations (pre-1950s levels) have not yet been reached (SAEFL 2002). 
Increases in acidic atmospheric deposition, i.e., the deposition of sulphur and nitrogen compounds, have been shown to accelerate soil acidification, possibly leading to toxic levels of aluminium or manganese in the plant-available soil water. The molar ratio between the exchangeable base nutrient cations $\mathrm{Ca}^{++}, \mathrm{Mg}^{++}$ and $\mathrm{K}^{+}(\mathrm{Bc})$ and aluminium $(\mathrm{Al}), \mathrm{Bc} / \mathrm{Al}$ in the soil solution, has been widely accepted as an indicator for plant toxicity (Sverdrup and Warfvinge 1993).

Furthermore, nitrogen can act as a fertilizer (Spiecker 1999a). In the case of nitrogen saturation (Aber et al. 1989), increased nitrogen concentrations in soil solution may also lead to nutrient imbalances for trees or to changes in the composition of ground vegetation and increased nitrate leaching into ground or surface waters.

$\mathrm{NO}_{\mathrm{x}}$ and other gases are precursors for tropospheric ozone $\left(\mathrm{O}_{3}\right)$. Uptake of $\mathrm{O}_{3}$ at ambient concentrations through the stomata and the related accumulation of reactive oxygen species within plant leaves can cause the collapse of parenchym cells leading to decreased rates of photosynthesis and plant growth (Kärenlampi and Skärby 1996). Ozone-induced injuries present a wide range of visible symptoms (e.g., Gravano et al. 2004; Innes et al. 1996, 2001; Novak et al. 2003).

In the framework of the Convention on LongRange Transboundary Air Pollution (LRTAP), the International Co-operative Program on the Assessment and Monitoring of Air Pollution Effects on Forests in Europe (ICP-Forests) was established in 1985 (de Vries et al. 2003; Fischer et al. 2005). The ICP-Forests program consists of (1) an annual survey of forest condition on several thousands of Level I plots, and (2) intensive monitoring of forest ecosystems including measurements of atmospheric deposition and air pollutants on about 800 Level II plots. In this context, the concept of critical loads and critical levels (CL) was introduced for the assessment of the effects of air pollution on ecosystems. The CL was defined at the Workshop in Skokloster (Nilsson and Grennfelt 1988) as "a quantitative estimate of an exposure to one or more pollutants below which significant harmful effects on specified elements of the environment do not occur according to present knowledge."

For forest ecosystems, critical loads for acidity $\left(\mathrm{CL}_{\mathrm{A}}\right)$ (Workshops in Skokloster 1988 and in Copenhagen 1999; see Nilsson and Grennfelt 1988), for nitrogen $\left(\mathrm{CL}_{\mathrm{N}}\right.$ ) (Workshops in Skokloster 1988, in Lökeberg
1992, in Geneva 1995, and in Berne 2002; see Achermann and Bobbink 2003; Grennfelt and Thörnelöf 1992) and critical levels of ambient $\mathrm{O}_{3}$ $\left(\mathrm{CL}_{\mathrm{O} 3}\right)$ (Workshops in Kuopio 1996, in Gerzensee 1999, and in Gothenburg 2002; see Kärenlampi and Skärby 1996; Karlsson et al. 2003) were determined or discussed based on the database available at that time, e.g., based on the ICP-Forests monitoring program. Maps of exceedances of critical values were refined using modelled $\mathrm{N}$ and $\mathrm{S}$ deposition and $\mathrm{O}_{3}$ concentrations (Posch et al. 2003). However, there is little literature comparing exceedance with the response of forest ecosystems (e.g., Reynolds et al. 1998). Furthermore, monitoring investigations within the ICP-Forests framework were conducted based on the critical loads and levels as defined in the past. In the meantime, however, the broad database of ICP-Forests as well as new findings have initiated further discussions about the air pollutant effects on forest ecosystems and the Level II approach (e.g., Graf Pannatier et al. 2004; Novak et al. 2003; Schaub et al. 2003; Schmitt et al. 2005; Suutari et al. 2001; Thimonier et al. 2005).

Thus, our objectives are (1) to assess the ecological risks, and (2) to evaluate the current CL concept based on the findings of the Swiss Long-Term Forest Ecosystem Research Programme (LWF), the Swiss contribution to the ICP-Forests Level II assessment.

In order to achieve these objectives, we estimated the exceedance of critical loads and levels on the Swiss Level II plots, and we compared indicators for possible effects with the respective levels of exceedance.

\section{Methods}

\subsection{Study sites}

The investigations on the Swiss Level II plots were carried out according to the guidelines as described within the ICP-Forests Manual (ICP-Forests 1998 and updates). The plots were selected according to various criteria including the relevance of the forest community type, the homogeneity, and the sensitivity to environmental changes (Cherubini and Innes 2000; Kräuchi 1996; Thimonier et al. 2001) and are located across the five main geographic regions of Switzerland (Fig. 1). Table 1 describes the main characteristics of the plots. 


\subsection{Sampling and measurements}

Each of the 16 Swiss Level II plots covers an area of 1-2 ha. This area includes a $43 \times 43 \mathrm{~m}$ intensive monitoring plot, subdivided into 16 subplots of $100 \mathrm{~m}^{2}$ with a spacing of $1 \mathrm{~m}$ between neighbouring subplots. Most measurements for this study were carried out on these subplots. On 13 Level II plots, we determined the solute fluxes in throughfall precipitation in the forest, as well as the fluxes in the bulk precipitation in a nearby open field, which was at a distance between 0.15 and $2.8 \mathrm{~km}$ from the respective forested stand. Sampling was carried out with snow (14 replicates) or rainfall (3-16 replicates) collectors and bi-weekly collection intervals as described in detail by Thimonier et al. (2005) for at least 1 year during the period from 1995 to 2001 for each plot. The total deposition of sulphur (S), nitrogen $(\mathrm{N})$, and the base cations $\mathrm{Ca}^{++}, \mathrm{Mg}^{++}, \mathrm{K}^{+}$, and $\mathrm{Na}^{+}(\mathrm{BC})$ was calculated annually based on the canopy budget model of Ulrich (1983), applying the equations recommended in the ICP-Forests Technical Report (de Vries et al. 2001) that include a ratio of 1:6 for the uptake of $\mathrm{NH}_{4}{ }^{+}$and $\mathrm{H}^{+}$by the canopy. On 16 Level II plots, layer-wise sampling and chemical analyses of the soil matrix (16 replications) were carried out during the period from 1995 to 1998 (Walthert et al. 2003). On 8 Level II plots, the soil solution was sampled at depths of 15 ,
50 and $80 \mathrm{~cm}$ every 2 weeks with suction cups (8 replicates) from 1999 to 2002, and analysed chemically as described by Graf Pannatier et al. (2004). The soil solutions was sampled throughout the year except at Celerina, where it was frozen during winter.

On 14 Level II plots, bi-weekly mean ozone concentrations (ppb) were measured throughout the 2002 growing season with passive samplers (Passam, Switzerland). These passive samplers were installed in triplicate at $2 \mathrm{~m}$ above ground level in the openfield next to the bulk deposition collectors (ICPForests Manual 1998). The measurement, data and quality assurance methods used in connection with these samplers are reported by Sanz, Calatayud, and Sanchez-Peña (2006).

In the same year, an assessment survey of symptoms of $\mathrm{O}_{3}$-induced visible injury was carried out at the light-exposed forest edge closest to the $\mathrm{O}_{3}$ monitoring site.

\subsection{Exceedances}

We applied the steady-state mass balance approach for calculating critical loads for acidity and nitrogen (Sverdrup and de Vries 1994) and the AOT40 approach for critical ozone levels and their exceedance (Fuhrer et al. 1997), both as described by the Mapping Manual of LRTAP (Spranger et al. 2004).
Fig. 1 Location of the Swiss Long-Term Forest Ecosystem Research (LWF)-plots (ICPForests Level II plots of Switzerland)

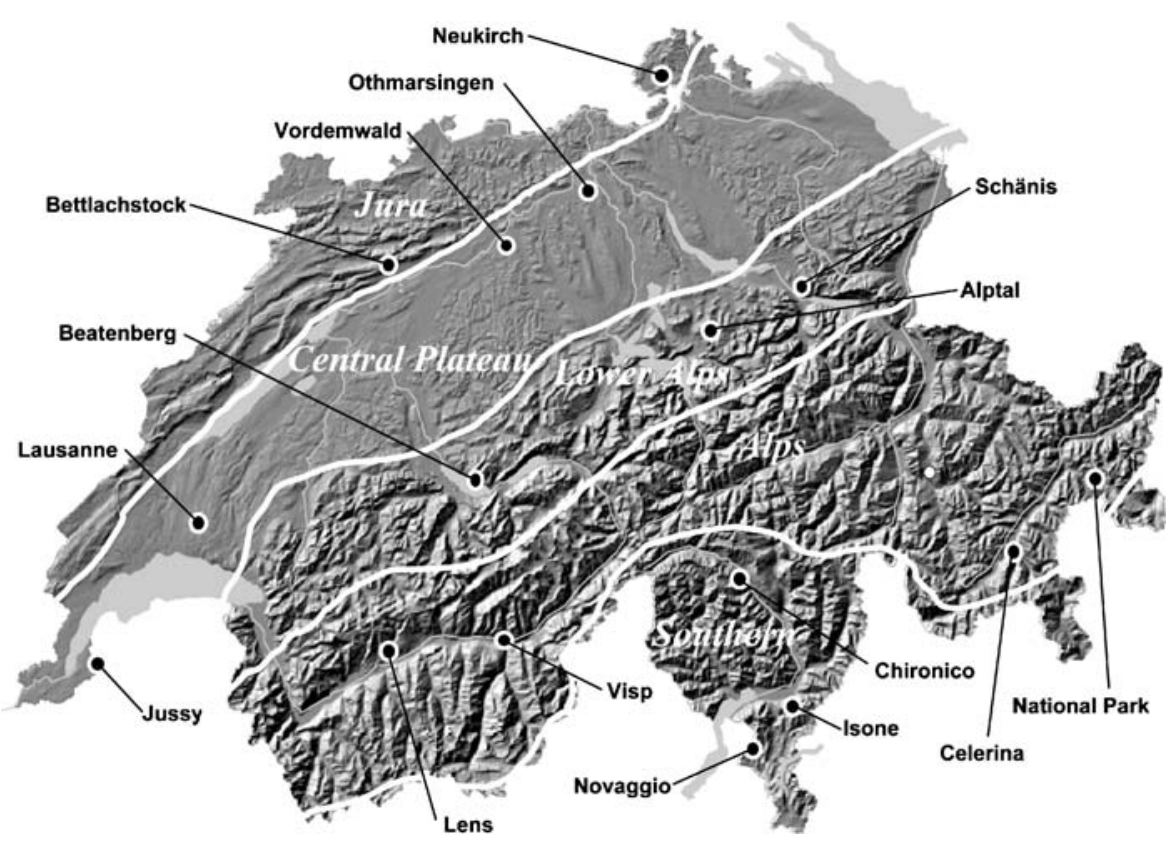




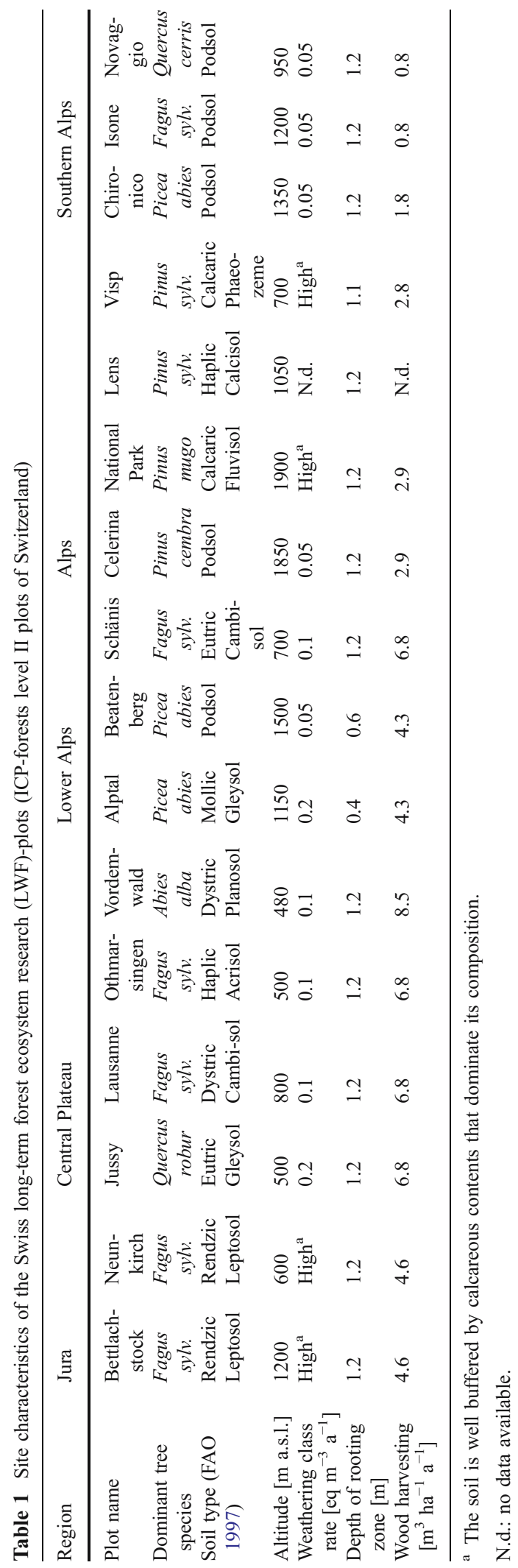

\subsubsection{Acidity}

The exceedance of the critical loads for acidity $\operatorname{ExCL}_{\mathrm{A}}$ (keq ha ${ }^{-1} \mathrm{a}^{-1}$ ) was calculated with

$\operatorname{ExCL}_{\mathrm{A}}=\mathrm{L}_{\mathrm{A}}-\mathrm{CL}_{\mathrm{A}}$

where $\mathrm{L}_{\mathrm{A}}$ (keq ha ${ }^{-1} \mathrm{a}^{-1}$ ) is the acid deposition and $\mathrm{CL}_{\mathrm{A}}$ (keq ha ${ }^{-1} \mathrm{a}^{-1}$ ) the critical load of acidity. $\mathrm{L}_{\mathrm{A}}$ was calculated with the following equation:

$\mathrm{L}_{\mathrm{A}}=\mathrm{TD}_{\mathrm{s}}+\mathrm{TD}_{\mathrm{N}}$

where $\mathrm{TD}_{\mathrm{S}}$ and $\mathrm{TD}_{\mathrm{N}}$ are the total atmospheric deposition of sulphur (S) and nitrogen $(\mathrm{N})$, and we used a factor of 2 and 1 eq $\mathrm{mol}^{-1}$ of deposited $\mathrm{S}$ and $\mathrm{N}$, respectively. The critical loads for acidity $\mathrm{CL}_{\mathrm{A}}$ were estimated based on the following equation:

$$
\begin{aligned}
\mathrm{CL}_{\mathrm{A}}= & \mathrm{TD}_{\mathrm{BC}}+\mathrm{BC}_{\mathrm{w}}-\mathrm{Bc}_{\mathrm{up}}^{\text {net }}+\mathrm{N}_{\mathrm{up}}^{\text {net }}+\mathrm{N}_{\mathrm{i}} \\
& +\mathrm{N}_{\mathrm{de}}-\mathrm{ANC}_{\mathrm{le}}^{\text {crit }}
\end{aligned}
$$

where $\mathrm{TD}_{\mathrm{BC}}\left(\mathrm{keq} \mathrm{ha} \mathrm{a}^{-1} \mathrm{a}^{-1}\right.$ ) is the total atmospheric deposition of base cations $\left(\mathrm{BC}=\mathrm{Ca}^{2+}, \mathrm{Mg}^{2+}, \mathrm{K}^{+}\right.$and $\mathrm{Na}^{+}$), $\mathrm{BC}_{\mathrm{w}}$ (keq ha- $\mathrm{a}^{-1}$ ) is the neutralization capacity produced by the weathering of base cations, $\mathrm{Bc}_{\text {up }}^{\text {net }}\left(\mathrm{keq} \mathrm{ha} \mathrm{a}^{-1} \mathrm{a}^{-1}\right)$ and $\mathrm{N}_{\text {up }}^{\text {net }}\left(\mathrm{keq} \mathrm{ha} \mathrm{a}^{-1} \mathrm{a}^{-1}\right)$ are the net uptake of base cations $\left(\mathrm{Bc}=\mathrm{Ca}^{2+}, \mathrm{Mg}^{2+}, \mathrm{K}^{+}\right)$and nitrogen in the tree biomass that is removed permanently from the system by wood harvesting, $\mathrm{N}_{\mathrm{i}}$ (keq $\mathrm{ha}^{-1} \mathrm{a}^{-1}$ ) the nitrogen immobilization rate in the soil, $\mathrm{N}_{\mathrm{de}}\left(\mathrm{keq} \mathrm{ha}^{-1} \mathrm{a}^{-1}\right)$ the denitrification rate, and $\mathrm{ANC}_{\mathrm{le}}^{\text {crit }}$ (keq ha $\mathrm{a}^{-1} \mathrm{a}^{-1}$ ) the critical leaching of acid neutralising capacity. $\mathrm{Bc}_{\mathrm{up}}^{\text {net }}$ was estimated by multiplying the regional mean wood harvesting volume with the mean wood density, the mean concentration of the base cations in the wood, and their charge (eq $\left.\mathrm{mol}^{-1}\right)$. $\mathrm{N}_{\mathrm{up}}^{\text {net }}$ was estimated similarly using a charge of 1 eq $\mathrm{mol}^{-1}$ for $\mathrm{N}$. The nitrogen immobilization rates $\mathrm{N}_{\mathrm{i}}$ were approximated according to Rihm's (1994) assignment of $\mathrm{N}_{\mathrm{i}}$ values to the soil types of the Swiss soil map. The denitrification was assumed to be neglegible, $\mathrm{N}_{\mathrm{de}}=0$. Two criteria were been applied to define $\mathrm{ANC}_{\mathrm{le}}^{\text {crit }}$ : (1) over long term, the ratio of $\mathrm{Bc} / \mathrm{Al}$ in the soil solution should remain higher than $1(\mathrm{Bc} / \mathrm{Al}>1)$ and (2) Al leaching $\left(\mathrm{Al}_{\mathrm{le}}^{3+}\right)$ should not be in excess of the $\mathrm{Al}$ produced by the weathering $\left(\mathrm{A} 1_{\mathrm{w}}^{3+}\right)$ of primary minerals $\left(\mathrm{A}_{1 \mathrm{e}}^{3+}<\mathrm{A} 1_{\mathrm{w}}^{3+}\right)$. The latter criteria aims at preventing the depletion of secondary $\mathrm{Al}$ phases and complexes which may cause structural changes in the soil. 
It is assumed that an excess of acidic inputs results in leaching of $\mathrm{H}^{+}$and $\mathrm{Al}^{3+}\left(\mathrm{H}_{\mathrm{le}}^{+}, \mathrm{Al}_{\mathrm{le}}^{3+}\right)$ from the soil, according to equation (4):

$\mathrm{ANC}_{1 \mathrm{e}}=\mathrm{H}_{\mathrm{le}}^{+}+\mathrm{A} 1_{\mathrm{le}}^{3+}$.

The gibbsite equilibrium equation (5) describes the relationship between the concentrations of $\mathrm{H}^{+}$and $\mathrm{Al}^{3+}$ in the weathering process, with

$$
\left[\mathrm{H}^{+}\right]=\frac{\left[\mathrm{Al}^{3+}\right]}{\mathrm{K}_{\text {Gibb }}^{1 / 3}}
$$

where $\mathrm{K}_{\text {Gibb }}$ is the gibbsite equilibrium constant.

For the conversion of concentrations into fluxes, we estimated the leaching water flux $\mathrm{Q}\left(\mathrm{mm} \mathrm{a}^{-1}\right)$ with

$\mathrm{Q}=\mathrm{P}-\mathrm{ET}-\mathrm{SR}$

where $\mathrm{P}\left(\mathrm{mm} \mathrm{a}^{-1}\right)$ is the measured precipitation, ET $\left(\mathrm{mm} \mathrm{a}^{-1}\right)$ the evapotranspiration, and SR $\left(\mathrm{mm} \mathrm{a}^{-1}\right)$ the surface runoff estimated with

$\mathrm{ET}=\mathrm{a}-\mathrm{H} \quad \mathrm{b}$

where $\mathrm{H}(\mathrm{m})$ is the altitude of the plot $\mathrm{a}=693 \mathrm{~mm}$ $\mathrm{a}^{-1}, \mathrm{~b}=0.18 \mathrm{~mm} \mathrm{a}^{-1} \mathrm{~m}^{-1}$ and

$\mathrm{SR}=0.1 \cdot \mathrm{P}$.

For $\mathrm{BC}_{\mathrm{W}}$, we used Rihm's (1994) estimates of specific weathering rate $\mathrm{BC}_{\mathrm{w}}^{\text {class }}\left(\right.$ eq $\left.\mathrm{m}^{-3} \mathrm{a}^{-1}\right)$ for each class of the Swiss soil map (Table 1) including his correction for the soil temperature $\mathrm{T}(\mathrm{K})$, hence

$\mathrm{BC}_{\mathrm{W}}=\mathrm{BC}_{\mathrm{W}}^{\text {class }} \cdot \mathrm{D}^{-\mathrm{C}_{1}\left(\frac{1}{\mathrm{~T}}-\frac{1}{\mathrm{C}_{2}}\right)} \cdot \mathrm{C}_{3}$

where $\mathrm{D}(\mathrm{m})$ is the depth of the rooting zone, $\mathrm{T}(\mathrm{K})$ the mean annual temperature $\mathrm{C}_{1}=3800 \mathrm{~K}, \mathrm{C}_{2}=283 \mathrm{~K}$ constants and $\mathrm{C}_{3}=104 \mathrm{~m}^{2} \mathrm{ha}^{-1}$ a unity conversion factor. In an initial run (I), we estimated $\mathrm{D}_{(\mathrm{I})}$ was $0.5 \mathrm{~m}$ for altitudes below $1600 \mathrm{~m}$ a.s.l. and $0.3 \mathrm{~m}$ for altitudes above $1600 \mathrm{~m}$ a.s.l using the method of Rihm (1994). In a second run (II), we estimated $D_{(I I)}$ as the depth to the uppermost limit for roots observed in the soil profile at the plot, such as a permanently oxygen-free horizon, a compact rock surface or a horizon with a fine material density higher than $1.8 \mathrm{~g}$ $\mathrm{cm}^{-3}$. We used $\mathrm{D}_{(\mathrm{II})}=1.2 \mathrm{~m}$ in case that no such limit was found to the depth of $1.2 \mathrm{~m}$.
The first criterion $(\mathrm{Bc} / \mathrm{Al}>1)$ as described above was applied by estimating $\mathrm{A} 1_{\mathrm{le}}^{3+}$ with $\mathrm{Bc} / \mathrm{Al}$ from the leaching of base cations $\left(\mathrm{Bc}_{\mathrm{le}}\right)$, with

$\mathrm{A}_{\mathrm{le}}^{3+}=\frac{1}{\mathrm{Bc} / \mathrm{A} 1} \mathrm{Bc}_{\mathrm{le}}$,

leading to the first equation (11) for $\mathrm{A} 1_{\mathrm{le}}^{3+}$ limitation:

$\mathrm{Al}_{\mathrm{le}}^{3+}<\mathrm{Bc}_{1 \mathrm{e}}$

For $\mathrm{Bc}_{\mathrm{le}}$ we used

$$
\begin{aligned}
\mathrm{Bc}_{1 \mathrm{e}}= & \mathrm{X}_{\mathrm{Bc} / \mathrm{BC}} \mathrm{BC}_{\mathrm{W}}+\mathrm{Bc}_{\mathrm{dep}}-\mathrm{Bc}_{\mathrm{up}}^{\text {net }} \\
& -\mathrm{Bc}_{1 \mathrm{e}(\min )} \mathrm{Q}
\end{aligned}
$$

where $\mathrm{X}_{\mathrm{Bc} / \mathrm{BC}}$ is between 0.6 and $0.8\left(\mathrm{eq} \mathrm{eq}^{-1}\right)$ and is the fraction of $\mathrm{Ca}^{++}, \mathrm{Mg}^{++}$, and $\mathrm{K}^{+}$of the base cations $\mathrm{Ca}^{++}, \mathrm{Mg}^{++}, \mathrm{K}^{+}$and $\mathrm{Na}^{+}$supplied by weathering.

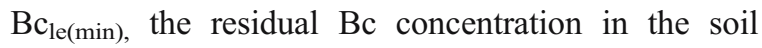
solution below which the trees are not able to take up base cations, was approximated as $15 \mathrm{eq} \mathrm{m}^{-3}$.

The second criterion $\left(\mathrm{A} 1_{\mathrm{le}}^{3+} \leq \mathrm{A} 1_{\mathrm{w}}^{3+}\right)$ was applied by using an approximate value of 1.5 for the $\mathrm{A}_{\mathrm{w}}^{3+}$ / $\mathrm{Bc}_{\mathrm{W}}$ ratio, which typically ranges from 1 to 3 :

$\mathrm{A}_{\mathrm{w}}^{3+}=1.5 \mathrm{Bc}_{\mathrm{W}}$,

leading to the second equation (14) for $\mathrm{Al}_{\mathrm{le}}^{3+}$ limitation:

$\mathrm{A}_{\mathrm{le}}^{3+} \leq 2.5 \mathrm{Bc}_{\mathrm{W}}$

The lower limit for $\mathrm{A}_{1 \mathrm{le}}^{3+}$ from the equations 11 and 14 was used to calculate $\mathrm{ANC}_{\mathrm{le}}^{\text {crit }}$ and the critical load of acidity $\left(\mathrm{CL}_{\mathrm{A}}\right)$.

\subsubsection{Nitrogen}

An empirical value for critical loads for nitrogen $\left(\mathrm{CL}_{\mathrm{N}}^{\mathrm{emp}}\right)$ in temperate forests, between 10 and $20 \mathrm{~kg}$ $\mathrm{ha}^{-1} \mathrm{a}^{-1}$, depending on plot characteristics, was determined at the Workshop in Berne in 2002 (Achermann and Bobbink 2003), and is currently recommended by the LRTAP.

Applying (i) the N saturation and (ii) the steadystate mass balance (SMB) concepts, we calculated the critical loads $\left(\mathrm{CL}_{\mathrm{N}}^{\mathrm{SMB}}\right)$ by taking some of the plot characteristics into account:

$\mathrm{CL}_{\mathrm{N}}^{\mathrm{SMB}}=\mathrm{N}_{\text {le(acc })}+\mathrm{N}_{\mathrm{u}}+\mathrm{N}_{\mathrm{i}}+\mathrm{N}_{\mathrm{de}}$ 
where $\mathrm{N}_{\mathrm{le}(\text { acc) }}$ of 4 and $5 \mathrm{~kg} \mathrm{ha}^{-1} \mathrm{a}^{-1}$ is the acceptable leaching of nitrogen compounds into the surface and subsurface waters for coniferous and deciduous forests, respectively. Here, the denitrification rate $\mathrm{N}_{\mathrm{de}}$ is approximated with the approach proposed by de Vries at the Workshop in Lökeberg (Grennfelt and Thörnelöf 1992),

$\mathrm{N}_{\mathrm{de}}=\mathrm{f}_{\mathrm{de}}\left(\mathrm{N}_{\mathrm{dep}}-\mathrm{N}_{\mathrm{u}}-\mathrm{N}_{\mathrm{i}}\right)$

applying Rihm's (1996) estimation of $f_{d e}$-values for the drainage condition classes used by the Swiss National Forest Inventory. These $f_{d e}$-values are comparable to the values proposed by Downing et al. (1993).

\subsubsection{Ozone}

The critical level for $\mathrm{O}_{3}$ was defined according to the AOT40 concept (Accumulated $\mathrm{O}_{3}$ over the Threshold of $40 \mathrm{ppb}$ ). The AOT40 value is calculated as the sum of the hourly ozone concentrations, $\left[\mathrm{O}_{3}\right]_{\mathrm{i}}(\mathrm{ppb})$, exceeding the threshold $\mathrm{C}_{4}=40 \mathrm{ppb}$ over the course of the vegetation period as defined from April 1 to September 30. Only daylight hours when global radiation $(\mathrm{R})$ exceeds $\mathrm{R}_{\text {min }}=50 \mathrm{~W} \mathrm{~m} \mathrm{~m}^{-2}$ are considered (Fuhrer and Achermann 1999; Kärenlampi and Skärby 1996):

$$
\text { AOT40 }=\sum_{\left[\mathrm{O}_{3}\right]_{\mathrm{i}}>\mathrm{C}_{4} \mathrm{R}>\mathrm{R}_{\min }}\left(\left[\mathrm{O}_{3}\right]_{\mathrm{i}}-\mathrm{C}_{4}\right)
$$

The critical AOT40 level for ozone $\left(\mathrm{CL}_{\mathrm{O} 3}\right)$ is based on the criteria to protect the trees from a $10 \%$ biomass loss and has been determined to be $5 \mathrm{ppm} \mathrm{h}$ (Workshop in Gothenburg 2002). Hourly ozone data $\left[\mathrm{O}_{3}\right]_{\mathrm{i}}$ were derived from the measured bi-weekly values based on the function of Loibl and Smidt (1996) which describes the ozone daily profile as a function of relative altitude. The detailed modelling methods for the hourly ozone concentrations are described by Gerosa et al. (2006).

\subsection{Effects}

\subsubsection{Acidification of the soil solution}

The $\mathrm{Bc} / \mathrm{Al}$ ratio $\left(\mathrm{mol} \mathrm{mol}{ }^{-1}\right)$ in the soil solution, where $\mathrm{Al}$ stands for the total dissolved aluminium concentration, was calculated for the 8 Level II plots where the soil solution was sampled. For plots without soil solution sampling, the $\mathrm{Bc} / \mathrm{Al}$ ratio was approximated from the base saturation BS in the soil matrix with

$\mathrm{Bc} / \mathrm{A} 1_{\mathrm{le}}=\mathrm{m} \cdot \mathrm{BS}$

where $\mathrm{m}=0.3$, i.e., the lower limit of the range of regression coefficients $(0.3-0.5)$ for the plots where soil solution and soil matrix have both been analyzed (Graf Pannatier et al. 2004).

In addition, the $\mathrm{Bc} / \mathrm{Al}^{3+}$ ratio, where only the $\mathrm{Al}^{3+}$ species is considered, was calculated for 5 Level II plots with acid mineral horizons (Graf Pannatier et al. 2004). We calculated the median of the $\mathrm{Bc} / \mathrm{Al}$ and $\mathrm{Bc} / \mathrm{Al}^{3+}$ ratio for each soil depth $(15,50$ and $80 \mathrm{~cm})$ and used the lowest of these three ratios as an indicator for the soil acidification status.

\subsubsection{Ozone injury}

Ozone-induced visible injury was reported in late summer 2002 within the framework of the ICPForests program on the Assessment of Ozone Injury on European Forest Ecosystems at the light-exposed forest edge of 16 Level II plots. Symptoms like ozone-induced visible injury observed on native tree and shrub species are validated against symptoms reproduced in open-top chamber facilities, such as in southern Switzerland at the Lattecaldo Cantonal Forest Nursery (e.g., Innes et al. 1996; Innes et al. 2001; Novak et al. 2003) and compared to the extensive ICP-Forests database for ozone injury (see http://www.gva.es/ceam/ICP-forests and http://www. ozone.wsl.ch).

\section{Results}

For acidity, the atmospheric deposition was calculated for 12 plots and ranged from 0.63 to $3.29 \mathrm{keq} \mathrm{ha}^{-1} \mathrm{a}^{-1}$ (Fig. 2). The lowest values resulted from low $\mathrm{S}$ and $\mathrm{N}$ inputs and were measured in the Alps at the plots of Celerina (0.64 keq ha $\left.{ }^{-1} \mathrm{a}^{-1}\right)$ and the National Park (0.63 keq ha $\left.{ }^{-1} \mathrm{a}^{-1}\right)$. For Visp and Lens, no deposition measurements were available. In the Lower Alps, on the Central Plateau and in the Jura, the values ranged from 1.02 to $1.96 \mathrm{keq} \mathrm{ha}^{-1} \mathrm{a}^{-1}$, except for Schänis, where the acid deposition was as high as $2.56 \mathrm{keq}$ 

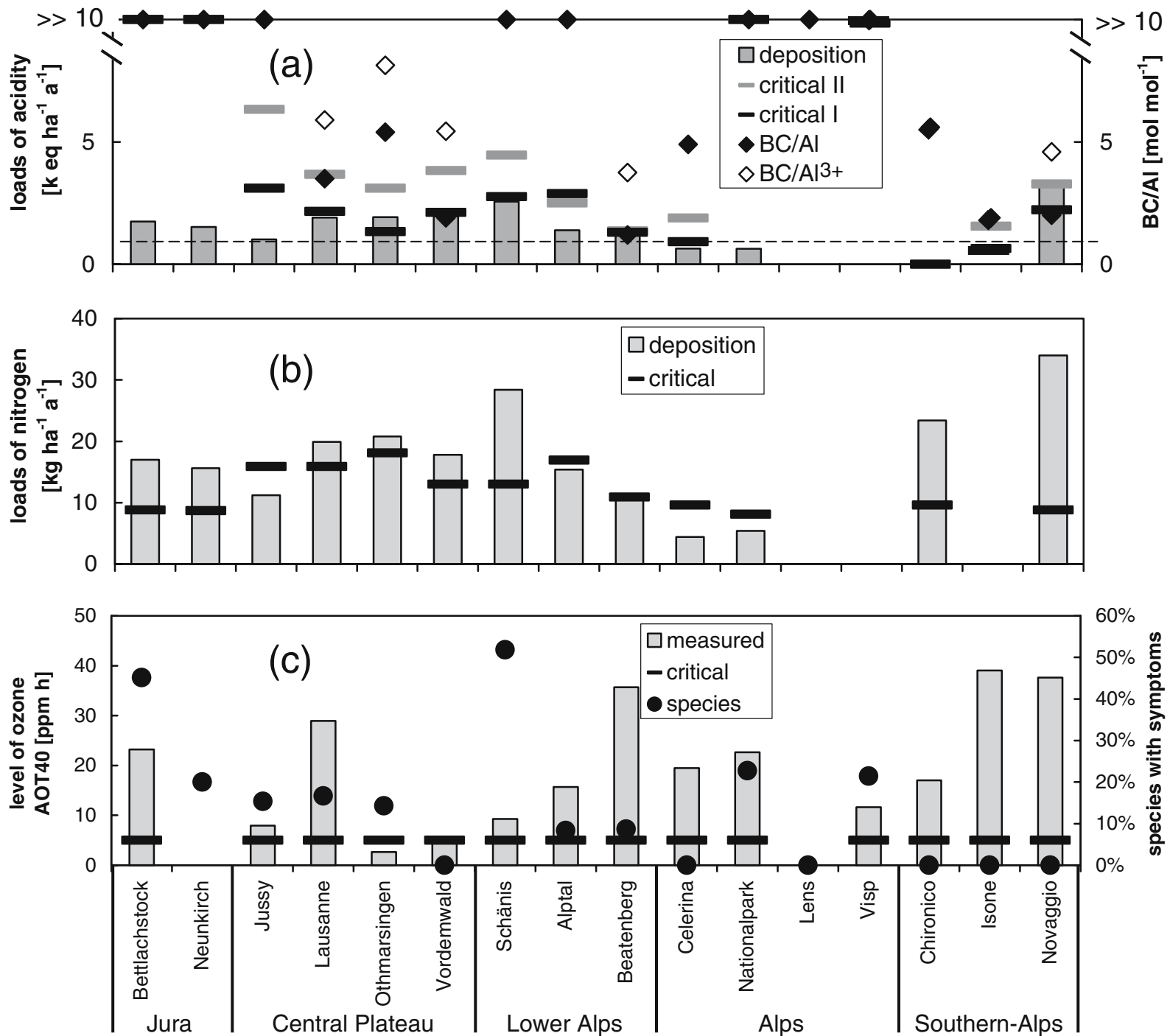

Fig. 2 (a) Atmospheric deposition and critical loads for acidity and the lowest of the median $\mathrm{Bc} / \mathrm{Al}$ and $\mathrm{Bc} / \mathrm{Al}^{3+}$ ratio in soil solution at 15,50 , or $80 \mathrm{~cm}$ depth. Critical loads were calculated with Rihm's (1994) estimate of the rooting zone depth (critical I) and with a rooting zone depth estimated based

$\mathrm{ha}^{-1} \mathrm{a}^{-1}$. The highest deposition was found at Novaggio in the Southern Alps. For Chironico and Isone, no values were available. The critical loads for acidity were very high at the plots in the Jura, at the National Park, and at Visp due to calcareous soils which buffer the acidic inputs. For the other plots, the critical loads for acidity were low. In general the rooting zone depths $\mathrm{D}_{(\mathrm{II})}$ estimated based on the soil profile examinations (Table 1) were higher than Rihm's (1994) estimate $\mathrm{D}_{\text {(I) }}$ (equation 9). Consequently the critical loads for the first run (I) were in general on soil profile examinations (critical II). (b) Atmospheric deposition and critical loads for nitrogen. (c) Measured and critical levels of ozone and percentage of species at a nearby forest edge with ozone-induced visible injury symptoms (2002) for ICP-Forests Level II plots of Switzerland

lower than those for the second run (II), except for Alptal (I: $2.9 \mathrm{keq} \mathrm{ha}^{-1} \mathrm{a}^{-1}$ II: 2.5) and Beatenberg (I: 1.3, II: 1.4). The acid deposition exceeded the critical loads of the first run (I) at 2 plots (at Novaggio by $1.0 \mathrm{keq} \mathrm{ha} \mathrm{a}^{-1}$ and at Othmarsingen by 0.6 ) and approached them at 4 plots (Lausannne, Vordemwald, Schänis, Beatenberg) but they did not exceed the critical loads of the second run (II) (Fig. 2).

The lowest $\mathrm{Bc} / \mathrm{Al}$ ratios in the soil profile (Fig. 2) were close to the critical value of 1 and were measured at Beatenberg (1.2), Vordemwald (1.9), 


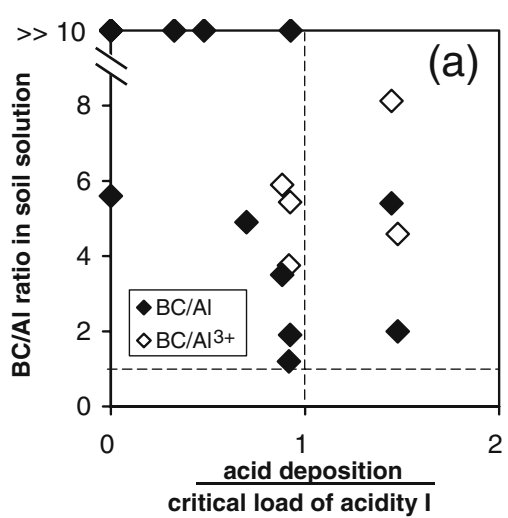

Fig. 3 (a) Lowest of the median $\mathrm{Bc} / \mathrm{Al}$ and $\mathrm{Bc} / \mathrm{Al}^{3+}$ ratio in soil solution at 15,50 or $80 \mathrm{~cm}$ depth plotted against the ratio of atmospheric deposition to critical loads for acidity I calculated in the initial run (I) with root zone depths according to Rihm (1994). (b) Lowest of the median $\mathrm{Bc} / \mathrm{Al}$ and $\mathrm{Bc} / \mathrm{Al}^{3+}$ ratio in soil solution at 15,50 or $80 \mathrm{~cm}$ depth plotted against the ratio

and Novaggio (2.0), where the acid deposition approached the critical loads. In contrast, the $\mathrm{Bc} / \mathrm{Al}$ ratios were much higher at Othmarsingen (5.4), Lausanne (3.5) and Schänis $(>10)$ although that the acid deposition approached or even exceeded the critical loads at these plots (see also Fig. 3a and b).

For N, deposition was available for 13 plots. It ranged from 4.4 to $34 \mathrm{~kg} \mathrm{~N} \mathrm{ha}^{-1} \mathrm{a}^{-1}$ and its pattern was similar to that for acid deposition. The critical loads for nitrogen $\left(\mathrm{CL}_{\mathrm{N}}^{\mathrm{SMB}}\right)$ were within the range from 8 to $20 \mathrm{~kg} \mathrm{~N} \mathrm{ha}^{-1} \mathrm{a}^{-1}$ and thus less variable than those for acidity. They were exceeded at Novaggio $\left(25 \mathrm{~kg} \mathrm{~N} \mathrm{ha}^{-1} \mathrm{a}^{-1}\right)$ and Chironico (14) in the Southern Alps, at Schänis (15) in the Lower Alps, and at 5 plots on the Central Plateau and in the Jura. Further, they were approached at the other 2 plots in the Lower Alps (Alptal and Beatenberg). In the Alps (Celerina and the National Park), the deposition of nitrogen was far below the critical load.

For ozone, actual AOT40 levels ranged from 2.6 to $39 \mathrm{ppm} \mathrm{h}$ in 2002 (Fig. 2) and its spatial pattern differed from that of the deposition. The highest levels were measured at Isone $(39.0 \mathrm{ppm} \mathrm{h})$ and Novaggio (37.6) in the Southern Alps, at Beatenberg (35.7) in the Lower Alps and at Lausanne (28.9) on the Central Plateau. The lowest levels were registered at Othmarsingen (2.6) and Vordemwald (5.3) on the Central Plateau. The critical AOT40 level of $5 \mathrm{ppm} \mathrm{h}$ was exceeded on 12 out of 14 plots.

Figure $3 \mathrm{c}$ shows the percentage of the species which were growing at the forest edge closest to the

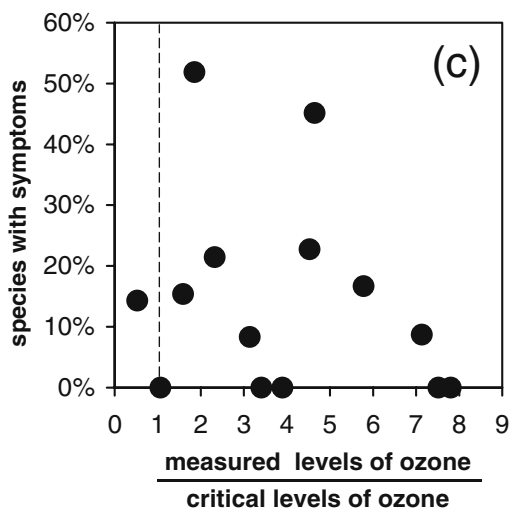

of atmospheric deposition to critical loads for acidity II calculated in the second run (II) with rooting zone depth estimated based on the soil profile examinations. $\mathrm{Bc} / \mathrm{Al}<1$ indicates aluminium toxicity. (c) Percentage of species at nearby forest edge with ozone-induced visible injury symptoms vs. ratio of actual ozone level over critical ozone level

plot and developed ozone-induced visible injury. Highest percentages of affected species were found at Schänis (52\%), Bettlachstock (45\%), National Park (23\%), and Visp (21\%). Despite high exceedances of the critical level, few symptoms of ozone-induced visible injury were found at Beatenberg (9\%), Alptal $(8 \%)$, and Lausanne $(17 \%)$ and no ozone-induced visible injury was found at Novaggio, Isone, and Celerina (Fig. 3c). Conversely, we found typical ozone-induced visible injury at Schänis (52\%) and Othmarsingen (14\%) although the critical AOT40 level was not exceeded there.

\section{Discussion}

The relatively high deposition loads of $\mathrm{S}$ and $\mathrm{N}$ at Novaggio and Schänis are typical for areas at the edge of sharply rising mountain chains in the proximity of industrialized and densely populated areas such as the Italian Po Plain and the Swiss Central Plateau (Della Lucia et al. 1996; Schmitt et al. 2005; Thimonier et al. 2005). These exposed areas are subjected to similar high pollutant concentrations in the air as in the plain, but receive higher precipitation. In contrast, Celerina and National Park are located within mountain chains, remote from densely populated areas.

Since around 1985, the loads of acidity have decreased in Europe, mainly due to a reduction in sulphur dioxide emissions from road traffic and industrial activities (SAEFL 2002). Klöti et al. 1989 
determined a sulphur deposition of about $1.8 \mathrm{keq} \mathrm{ha}^{-1}$ $\mathrm{a}^{-1}$ at Lägern in the Central Plateau of Switzerland between June 1986 and June 1987, while our annual values for $\mathrm{S}$ deposition between 1995 and 2001 ranged from 0.1 to $1.0 \mathrm{keq} \mathrm{ha}^{-1} \mathrm{a}^{-1}$. In comparison, in 1988 during the massive forest decline, Dambrine et al. (1993) measured $\mathrm{S}$ and $\mathrm{N}$ deposition of 4 and $3 \mathrm{keq} \mathrm{ha}{ }^{-1} \mathrm{a}^{-1}$, respectively, at Naèetin in the Krušné hory Mts. (Erzgebirge, Czech Republik) where the soils are poorly buffered. According to Kurz et al. (1998), the critical loads for acidity were exceeded for about $60 \%$ of the forested area in Switzerland using the 1986-1990 acid deposition. They determined median acid deposition of about $3.5,4.5$ and $2.5 \mathrm{k}$ eq ha ${ }^{-1} \mathrm{a}^{-1}$ for the Jura, the Central Plateau, and the Alps, respectively. Hence, the reduction of sulphur emission successfully decreased the acid deposition to below the critical loads for acidity for numerous plots (see also Posch et al. 1999).

However, the critical loads for acidity presented here include uncertainties such as the estimate of the weathering rate as shown by varying the main rooting zone depths (D), applied in equation (9). Our impression that Rihm's (1994) estimate of D seems to underestimate the rooting zone depths remains to be proven. Moreover, the uncertainty of the specific weathering rate could be reduced substantially by including the soil chemistry and mineralogy measurements into the calculations of the weathering rates and by using dynamic models. Such a soil chemistry model (PROFILE) was applied by Kurz et al. (1998) for 770 sites in Switzerland with a known chemistry of the soil matrix, but the model has neither been calibrated nor validated with Swiss soil solution chemistry measurements.

No relationship could be found between the exceedance of critical loads and the $\mathrm{Bc} / \mathrm{Al}$ ratios. The field data indicate that the ecological risks related to the critical $\mathrm{Bc} / \mathrm{Al}$ ratio might be lower than those estimated with the model. When determining the speciation for $\mathrm{Al}$ in the soil solution, Graf Pannatier et al. (2004) found that much of the $\mathrm{Al}$ consists of less toxic $\mathrm{Al}$ species rather than $\mathrm{Al}^{3+}$ at Beatenberg and Vordemwald. At Vordemwald, Othmarsingen, and Lausanne, the lowest $\mathrm{Bc} / \mathrm{Al}$ ratios were found in the uppermost layer at $15 \mathrm{~cm}$ depth with increasing values towards the lower layers (Graf Pannatier et al. 2004). Adapted root systems may compensate for the low ratio in the topsoil by increased uptake of base cations from lower layers (Walthert et al. 2006). In addition, Grigal and Ohmann (2005) have shown that upwards diffusion of cations may also be important and should be considered for the CL models. In contrast, at Beatenberg, the lowest $\mathrm{Bc} / \mathrm{Al}$ ratio was recorded at $80 \mathrm{~cm}$ depth in the mineral layer clearly below the rooting zone and may thus not affect the plant roots (Graf Pannatier et al. 2004).

However, the concept is based on the steady-state assumption, although the atmospheric deposition has changed in the past few decades. Therefore, the $\mathrm{Bc} / \mathrm{Al}$ ratio is not necessarily expected to correlate to the exceedance at the moment, but over long-term. As the soil solution sampling on the Swiss Level II plots started only in 1999, no trend analysis could be conducted for $\mathrm{Bc} / \mathrm{Al}$ ratios. Consequently, we have no information whether the measured state is the result of soil formation or it is, in addition, influenced by accelerated soil acidification during the last few decades. Long-term measurements of the $\mathrm{Bc} / \mathrm{Al}$ ratio at Copera in Southern Switzerland showed a decreasing trend during the last 16 years (Graf Pannatier et al. 2005). Hence, despite the successful reduction of the sulphur emission, a long-term risk of an accelerated soil acidification is still likely for some forested areas in Switzerland with poorly buffered soils and high atmospheric deposition of acidity, e.g., at Novaggio. One possible effect, a lower storm resistance of trees, has been recently discussed by Mayer et al. (2005) and others.

The atmospheric deposition of nitrogen still exceeded the critical loads for a number of plots, in particular for two plots in the Southern Alps (Novaggio: $\mathrm{TD}_{\mathrm{N}}-\mathrm{CL}_{\mathrm{N}}^{\mathrm{SMB}}=25.2 \mathrm{~kg} \mathrm{~N} \mathrm{ha}^{-1} \mathrm{a}^{-1}$, Chironico: 13.8) and for one plot in the Lower Alps (Schänis: 15.4). The high $\mathrm{N}$ deposition is largely related to the emissions from road traffic, agriculture, industry, and heating systems in Switzerland and the neighbouring countries. Most of the calculated $\mathrm{CL}_{\mathrm{N}}^{\mathrm{SMB}}$ were within the range of $\mathrm{CL}_{\mathrm{N}}^{\mathrm{EMP}}$. The $\mathrm{SMB}$ calculations of the critical loads for nitrogen include uncertainties, especially the terms of $\mathrm{N}_{\mathrm{de}}$ and $\mathrm{N}_{\mathrm{i}}$. The uncertainties might be in the range of the difference between calculated deposition and critical loads for up to about 7 plots. Further, the SMB concept does not take into account the actual $\mathrm{N}$ saturation status of a plot. At Alptal for example, experimentally added $\mathrm{N}$ was still immobilized in the soil (Schleppi et al. 1998) and we suppose that many other sites are not yet $\mathrm{N}$ saturated. 
Increasing soil $\mathrm{N}$ pools can be remobilized after disturbances such as clear-cuts or storm damage (Hegg et al. 2004). Consequently, the atmospheric deposition of nitrogen may represent a long-term risk for forest ecosystems at several sites in Switzerland leading to increasing growth rates, nutrient imbalances, or reduced stress tolerance for trees and increased nitrate leaching (see, e.g., Flückiger and Braun 1999; Mayer et al. 2005; Spiecker 1999b).

The levels of ozone on 14 Swiss Level II plots were spatially variable and the AOT40 values ranged from 2.6 to $39 \mathrm{ppm} \mathrm{h}$. The high levels at Isone (39.0 ppm h), Novaggio (37.6), Beatenberg (35.7), Lausanne (28.9) and Bettlachstock (23.2) might be related to (1) the proximity of these plots to emission sources such as intensively used traffic axes and industrialized agglomerations, and (2) to the exposure of the emitted precursors to sunlight and high temperatures. Slightly or considerably lower levels were registered at plots which are very remote from larger cities such as the National Park (22.6), Celerina (19.5), and Alptal (15.7). Yet, lowest levels were recorded at plots in close vicinity of $\mathrm{NO}_{\mathrm{x}}$ emission sources such as Othmarsingen (2.6) and Vordemwald (5.3). These low levels can be explained by the fact that high $\mathrm{NO}_{\mathrm{x}}$ levels enhance ozone decomposition.

The levels of ozone exceeded the critical AOT40 value at 12 out of 14 plots. The derivation of AOT40 values from bi-weekly passive sampling measurements implies some uncertainty. Furthermore, ozone concentrations are subject to high inter-annual variability and we included measurements from 2002 only. The species composition at the forest edges and their sensitivity to ozone differ from plot to plot. This limits the comparability of the quota of plant species showing ozone-induced visible injury versus $\mathrm{O}_{3}$ tolerant species.

On the other hand, plants may respond to increased vapour pressure deficit and reduced soil water availability by reducing the stomatal opening, leading to a reduced $\mathrm{O}_{3}$ uptake despite peak ozone levels (e.g., Schaub et al. 2003). This influence by environmental site conditions is not taken into account with the AOT40 concept as stated for example by G. P. Karlsson, P. E. Karlsson, Soja, Vanermeiren, and Pleijel (2004). In the Southern Alps, for example, in particular at Novaggio and Isone, high summer temperatures combined with low relative humidity leading to high vapour pressure deficits at the leaf level limit the stomatal uptake. These conditions are common and frequent for southern Switzerland, which may explain the lack of ozone-induced visible injury despite of the occurrence of some of the highest $\mathrm{O}_{3}$ concentration values across Europe. In order to take the influence of environmental factors on the physiological plant behaviour into account, the estimate of a critical $\mathrm{O}_{3}$ uptake may be more biologically relevant than the concentration based AOT40 concept (e.g., Matyssek et al. 2004).

\section{Conclusions}

The atmospheric deposition of acidity exceeded the critical loads at 2 plots and approached them at 4 out of 12 Swiss Level II plots. Therefore, we cannot exclude long-term ecological risks related to $\mathrm{Al}$ toxicity and $\mathrm{Al}$ depletion in Switzerland in areas with high deposition loads of acidity and poorly-buffered soils. The results of the critical loads calculations with the steady-state mass balance showed no relationship with the measured $\mathrm{Bc} / \mathrm{Al}$ ratio in the soil solution, but we cannot exclude a correlation in future when the system reaches steady state. However, the frequently used method that we applied here includes a large uncertainty due to estimation method of the weathering rate. The calculation of critical loads could be substantially improved by (1) modelling the weathering process based on the physical and chemical measurements on the plots, (2) using dynamic models, (3) validating the models with the measured soil solution chemistry, (4) including $\mathrm{Al}$ speciation, and (5) cation diffusion. In addition, long-term soil solution chemistry data are of key importance for the assessment of the soil acidification risk in Swiss forests.

For nitrogen, the critical loads were clearly exceeded for 3 out of 5 Swiss Level II plots in the Lower and the Southern Alps, whereas they were not exceeded at the plots in sparsely populated areas in the Alps. In the Jura and on the Central Plateau, the critical loads were lower but were still exceeded at 5 out of 6 plots. Considering calculation uncertainties, the actual deposition is likely to represent a long-term risk for 3 to 10 out of 13 plots. In the long-term, such exceedance may lead to increasing tree growth, decreased stress tolerance of trees, nutrient imbalan- 
ces, changes in species composition, and increased nitrate leaching into ground water.

Critical levels of $\mathrm{O}_{3}$ were exceeded on 12 out of 14 Swiss Level II plots. The quota of the plant species showing ozone-induced visible injury does not correspond to the exceedance of the AOT40 critical level of $5 \mathrm{ppm} \mathrm{h} \mathrm{O}_{3}$. Partly, this lack of correlation may be due to the differing species composition of $\mathrm{O}_{3}$ sensitive versus $\mathrm{O}_{3}$-tolerant species. Another source of uncertainty may lie in the estimation of the AOT40 statistics based on data from bi-weekly passive sampling. The variation due to the differing species composition among plots may be eliminated with the planting of $\mathrm{O}_{3}$-sensitive bio-indicator species, which would allow a sound comparison of onset and severity of negative ozone effects such as visible injury among the plots. The calculation of the effective ozone uptake rather than the exceedance of a certain concentration-based threshold, in combination with the bio-indicator approach would, furthermore, allow a more biologically meaningful ozone risk assessment for forest ecosystems.

Acknowledgments We are grateful to A. Brechbühl, N. Hajjar, O. Schramm, D. Christen, A. Zürcher and former laboratory staff (A. Ottiger, P. Weibel, K. Meier, S. Mullis, N. Holzer, J. Sierra, D. Nievergelt and B. Peter) for the sample handling in the field as well as in the laboratory, the foresters and local collaborators (A. Cuonz, R. Favre, F. Filli, L. Frigerio, L. Grob Kotlaris, T. Grossniklaus, Stalder, M. Leimer, O. Mayor, U. Meierhofer, B. Meister, T. Studer, W. Thoma and P. Zumstein) for collecting the samples on the LWF-plots, with special thanks to C. Hug, G. Schneiter, D. Trummer and U. Zehnder. We would like to thank D. Pezzotta and the staff of the WSL central laboratory for analyzing the samples, P. Jakob for the database support, L. Bernhard for generating the map, $\mathrm{K}$. Novak and S. Bassin for the field assessments of ozoneinduced visible injury at the Level II plots.

We are grateful to the Federal Office for the Environment (FOEN) for their financial support. The field work was partially supported by the Cantons St. Gallen and Valais, the village of Celerina, as well as the city of Lausanne.

\section{References}

Aber, J. D., Nadelhoffer, K. J., Steudler, P., \& Melillo, J. M. (1989). Nitrogen saturation in northern forest ecosystems. Bioscience, 39, 378-386.

Achermann, B., \& Bobbink, R. (2003). Report of the Workshop 'Empirical Critical Loads for Nitrogen. November 11-13, 2002, Berne, Convention on Long-Range Transboundary
Air Pollution (LRTAP), UN-ECE, Environmental Documentation, 164, Swiss Agency for the Environment, Forests and Landscape, Berne.

Cherubini, P., \& Innes, J. L. (2000). Switzerland: The Swiss Long-Term Forest Ecosystem Research programme. In J. R. Gosz, C. French, P. Sprott \& M. White (Eds.), The international long term ecological research network. Perspectives from participating networks, U.S. long term ecological research network office (pp. 56-59). Albuquerque, N.M.: University of New Mexico.

Dambrine, E., Kinkor, V., Jehlicka, J., \& Gelhaye, D. (1993). Fluxes of dissolved mineral elements through a forest ecosystem submitted to extremely high atmosphericpollution inputs (Czech Republic). Annals of Forest Science, 50, 147-157.

Della Lucia, M., Marchetto, A., Mosello, R., \& Tartari, G. A. (1996). Studies on a chemical gradient of atmospheric deposition from the Po Valley to the Alps. Water, Air and Soil Pollution, 87, 171-187.

de Vries, W., Reinds, G. J., van der Salm, C., Draaijers, G. P. J., Bleeker, A., Erisman, J. W., et al. (2001). Intensive monitoring of forest ecosystems in Europe, Technical report, International Co-operative Programme on assessment and monitoring of air pollution effects on forests (ICP-Forests), Convention on Long-Range Transboundary Air Pollution (LRTAP) (p. 177). Brussels, Geneva: UN-ECE.

de Vries, W., Vel, E., Reinds, G. J., Deelstra, H., Klap, J. M., Leeters, E. E. J. M., et al. (2003). Intensive monitoring of forest ecosystems in Europe. Forest Ecology and Management, 174, 77-115.

Downing, R. J., Hettelingh, J. P., \& de Smet, P. A. M. (1993). Calculation and mapping of critical loads in Europe, Status Report, Coordination Centre for Effects (CCE), Working Group on Effects (wge), Convention on Long-range Transboundary Air Pollution (LRTAP), UN-ECE, Coordination Center for Effects, National Institute for Public Health and Environmental Protection (RIVM) (p. 163). Bilthoven, The Netherlands.

FAO (1997). FAO-UNESCO soil map of the world. Updated reprint of World Resources Report 60, FAO, Rome. Technical Paper 20. Wageningen: International Soil Reference and Information Centre (ISRIC).

Fischer, R., Bastrup-Birk, A., Becker, R., Catalayud, V. (2005). The condition of forests in Europe. Executive Report, International Co-operative Programme on Assessment and Monitoring of Air Pollution Effects on Forests (ICPForests), Convention on Long-range Transboundary Air Pollution (LRTAP), UN-ECE, Federal Research Centre for Forestry and Forest Products (BFH) (p. 33). Germany.

Flückiger, W., \& Braun, S. (1999). Nitrogen and its effect on growth, nutrient status and parasite attacks in beech and Norway spruce. Water, Air and Soil Pollution, 116, 99-110.

Fuhrer, J., \& Achermann, B. (1999). Report of the workshop Critical levels for ozone-level II. April 11-15, 1999, Gerzensee, Switzerland, Environmental Documentation, 115, Swiss Agency for the Environment, Forests and Landscape. Bern, Switzerland.

Fuhrer, J., Skärby, L., \& Ashmore, M. R. (1997). Critical levels for ozone effects on vegetation in Europe. Environmental Pollution, 97, 91-106. 
Gerosa, G., Ferretti, M., Bussotti, F. \& Rocchini, D. (2006). Estimates of ozone AOT40 from passive sampling in forest sites in South-Western Europe. Environmental Pollution (in press).

Graf Pannatier, E., Luster, J., Zimmermann, S., \& Blaser, P. (2005). Acidification of soil solution in a chestnut forest stand in Southern Switzerland: Are there signs of recovery. Environmental Science and Technology, 39, 7761-7767.

Graf Pannatier, E., Walthert, L., \& Blaser, P. (2004). Solution chemistry in acid forest soils: Are the BC: Al ratios as critical as expected in Switzerland? Journal of Plant Nutrition and Soil Science, 167, 160-168.

Gravano, E., Bussotti, F., Strasser, R. J., Schaub, M., Novak, K., Skelly, J., et al. (2004). Ozone symptoms in leaves of woody plants in open-top chambers: Ultrastructural and physiological characteristics. Physiologia Plantarum, 121, 620-633.

Grennfelt, P., \& Thörnelöf, E. (1992). Report of the Workshop Critical Loads for Nitrogen (p. 428). April 6-12, 1992, Lökeburg, Sweden, Convention on Long-Range Transboundary Air Pollution (LRTAP), UN-ECE, Report, 1992:41. Copenhagen: Nordic Council of Ministers.

Grigal, D. F., \& Ohmann, P. R. (2005). Calcium and forest systems: Diffusion from deep sources. Soil Science, 170, 129-136.

Hegg, C., Jeisy, M., \& Waldner, P. (2004). Wald und Trinkwasser. Eine Literaturstudie (p. 60), Eidg. Forschungsanstalt für Wald, Schnee und Landschaft, WSL, Birmensdorf.

ICP-Forests (1998). Manual on methods and criteria for harmonized sampling, assessment, monitoring and analysis of the effects of air pollution on forests (p. 177). Manual, International Co-operative Programme on Assessment and Monitoring of Air Pollution Effects on Forests (ICP-Forests), Convention on Long-Range Transboundary Air Pollution (LRTAP), UN-ECE., Programme Coordinating Centres, Hamburg, Prague.

Innes, J. L., Skelly, J. M., Landolt, W., Hug, C., Snyder, K. R., \& Savage, J. E. (1996). Development of visible injury on the leaves of Prunus serotina in Ticino, southern Switzerland, as a result of ozone exposure. Preliminary results. In M. Knoflacher, J. Schneider \& G. Soja (Eds.), Report of the Workshop Exceedance of critical loads and levels (pp. 146-154). November 22-24, 1995, Vienna, Austria, Convention on Long Range Transboundary Air Pollution (LRTAP), UN-ECE. Vienna: Bundesministerium für Umwelt, Jugend und Familie.

Innes, J. L., Skelly, J. M., \& Schaub, M. (2001). Ozone and broadleaved species. A guide to the identification of ozone-induced foliar injury (p. 136). Paul Haupt Verlag, Berne: Swiss Federal Institute for Forest, Snow and Landscape Research (WSL).

Kärenlampi, L., \& Skärby, L. (1996). Report of the Workshop Critical levels for ozone in Europe: Testing and finalizing the concepts. April 15-17, 1996, Kuopio, Finnland, Convention on Long-Range Transboundary Air Pollution (LRTAP), UN-ECE, Department of Ecology and Environmental Science, Kuopio, Finland.

Karlsson, G. P., Karlsson, P. E., Soja, G., Vanermeiren, K., \& Pleijel, H. (2004). Test of the short-term critical levels for acute ozone injury on plants-improvements by ozone uptake modelling and the use of an effect threshold. Atmospheric Environment, 38, 2237-2245.
Karlsson, P. E., Selldéen, G., \& Pleijel, H. (2003). Report of the workshop Establishing ozone critical levels II. November 1922, Gothenburg, Sweden, 2002, Convention on Long-Range Transboundary Air Pollution (LRTAP), UN-ECE, Report B 1523, Swedish Environmental Institute IVL, Sweden.

Klöti, P., Keller, H., \& Guecheva, M. (1989). Effects of forest canopy on throughfall precipitation chemistry (Vol. 179, pp. 203-209). In 'Baltimore Symposium', Baltimore, May 10-19, 1989. International Association of Hydrological Sciences (IAHS) Publication.

Kräuchi, N. (1996). Long-term forest monitoring in Switzerland: Assessing climate change impacts. World Resource Review, 8, 370-381.

Kurz, D., Rihm, B., Sverdrup, H., \& Warfvinge, P. (1998). Critical loads of acidity for forest soils. Regionalized PROFILE model (p. 102). Environmental Documentation, 88, Swiss Agency for the Environment, Forests and Landscape (SAEFL), Berne.

Loibl, W., \& Smidt, S. (1996). Ozone exposure-Areas of potential ozone risk for selected tree species. Environmental Science and Pollution Research, 3(4), 213-217.

Matyssek, R., Wieser, G., Nunn, A. J., Kozovits, A. R., Reiter, I. M., Heerdt, C., et al. (2004). Comparison between AOT40 and ozone uptake in forest trees of different species, age and site conditions. Atmospheric Environment, 38, 2271-2281.

Mayer, P., Brang, P., Dobbertin, M., Hallenbarter, D., Renaud, J. P., Walthert, L., et al. (2005). Forest storm damage is more frequent on acidic soils. Annals of Forest Science, $62,303-311$.

Nilsson, J., \& Grennfelt, P. (1988). Report of the Workshop 'Critical loads for sulphur and nitrogen (p. 418). March 19-24, 1988, Skokloster, Sweden, Convention on LongRange Transboundary Air Pollution (LRTAP), UN-ECE, Nordic Council of Ministers, Copenhagen.

Novak, K., Skelly, J. M., Schaub, M., Kräuchi, N., Hug, C., Landolt, W., et al. (2003). Ozone air pollution and foliar injury development on native plants of Switzerland. Environmental Pollution, 125, 41-52.

Percy, K. E., \& Ferretti, M. (2004). Air pollution and forest health: Toward new monitoring concepts. Environmental Pollution, 130, 113-126.

Posch, M., Hetteling, J.-P., Slootweg, J., \& Downing, R. J. (2003). Calculation and mapping of critical tresholds in Europe. Status Report, Coordination Centre for Effects (CCE), Working Group on Effects (wge), Convention on Long-range Transboundary Air Pollution (LRTAP), UN-ECE, National Institute of Public Health and the Environment (RIVM), Bilthoven, Netherlands.

Posch, M., Hettelingh, J. P., de Smet, P. A. M., \& Downing, R. J. (1999). Calculation and mapping of critical thresholds in Europe (p. 154). Status Report, Coordination Centre for Effects (CCE). Working Group on Effects (wge). Convention on Long-range Transboundary Air Pollution (LRTAP), UN-ECE, Coordination Centre for Effects, National Institute for Public Health and Environmental Protection (RIVM), Bilthoven, The Netherlands.

Reynolds, B., Wilson, E. J., \& Emmett, B. A. (1998). Evaluating critical loads of nutrient nitrogen and acidity for terrestrial systems using ecosystem-scale experiments (NITREX). Forest and Ecology Management, 101, 81-94. 
Rihm, B. (1994). Critical loads of acidity for forest soils and alpine lakes. Steady state mass balance method (p. 68). Environmental Series, 234, Swiss Federal Office of Environment, Forests and Landscape (FOEFL), Bern.

Rihm, B. (1996). Critical loads of nitrogen and their exceedances-Eutrophying atmospheric deposition (p. 74). Environmental Series, 275, Swiss Federal Office of Environment, Forests and Landscape (FOEFL), Bern.

SAEFL (2002). Environment Switzerland (p. 356). Berne: Swiss Agency for Environment, Forest and Landscape (SAEFL).

Sanz, M. J., Catalayud, V., \& Sánchez-Peña, G. (2006). Measures of ozone concentrations using passive sampling in forests of South Western Europe. Environmental Pollution (in press).

Schaub, M., Skelly, J. M., Steiner, K. C., Davis, D. D., Pennypacker, S. P., Zhang, J., et al. (2003). Physiological and foliar injury responses of Prunus serotina, Fraxinus americana, and Acer rubrum seedlings to varying soil moisture and ozone. Environmental Pollution, 124, 307-320.

Schleppi, P., Muller, N., Feyen, H., Papritz, A., Bucher, J. B., \& Flühler, H. (1998). Nitrogen budgets of two small experimental forested catchments at Alptal, Switzerland. Forest and Ecology Management, 101, 177-185.

Schmitt, M., Thöni, L., Waldner, P., \& Thimonier, A. (2005). Total deposition of nitrogen on Swiss Long-term Ecosystem Research (LWF) plots: Comparison of the throughfall and the inferential method. Atmospheric Environment, 39, 1079-1091.

Spiecker, H. (1999a). Forest growth responses to the pollution climate of the 21st Century. Water, Air and Soil Pollution, $116,33-46$.

Spiecker, H. (1999b). Overview of recent growth trends in European forests. Water, Air and Soil Pollution, 116, 33-46.

Spranger, T., Smith, R., Fowler, D., Mills, G., Posch, M., Hall, J., et al. (2004). Modelling and Mapping Critical Loads and Levels and Air Pollution Effects, Risks and Trends (p. 236). Report, International Co-operative Programme for Modelling and Mapping, Convention on Long-range Transboundary Air Pollution (LRTAP). UN-ECE, http:// www.icpmapping.org

Suutari, R., Amann, M., Cofala, J., Klimont, Z., Posch, M., Schöpp, W. (2001). From economic activities to ecosystem protection in Europe. An uncertainty analysis of two scenarios of the RAINS integrated assessment model (p. 65). Report, EMEP, CIAM, Convention on Long-range Transboundary Air Pollution (LRTAP). UN-ECE, Coordination Center for Effects, National Institute for Public Health and Environmental Protection (RIVM), Bilthoven, The Netherlands.

Sverdrup, H., \& de Vries, W. (1994). Calculating critical loads for acidity with the simple mass balance method. Water, Air and Soil Pollution, 72, 143-162.

Sverdrup, H., \& Warfvinge, P. (1993). The effect of soil acidification on the growth of trees, grasses and herbs as expressed by the $(\mathrm{Ca}+\mathrm{Mg}+\mathrm{K}) / \mathrm{Al}$ ratio. Reports in Ecology and Environmental Engineering, 1993:2. Sweden: Department of Chemical Engineering II, Lund University.

Thimonier, A., Schmitt, M., Cherubini, P., \& Kräuchi, N. (2001). Monitoring the Swiss forest: Building a research platform. In T. Anfodillo \& V. Carraro (Eds.), Monitoraggio ambientale: Metodologie ed applicazioni. Atti del XXXVIII 'Corso di Cultura in Ecologia. (pp. 121-134). San Vito di Cadore, Centro Studi per l'Ambiente Alpino, Università degli Studi di Padova.

Thimonier, A., Schmitt, M., Waldner, P., \& Rihm, B. (2005). Atmospheric deposition on Swiss Long-term Forest Ecosystem Research (LWF) plots. Environmental Monitoring and Assessment, 104, 81-118.

Ulrich, B. (1983). Interaction of forest canopies with atmospheric constituents: SO2, alkali and earth alkali cations and chloride. In B. Ulrich \& J. Pankrath (Eds.), Effects of accumulation of air pollutants in forest ecosystems (pp. 33-45). Dordrecht: Reidel.

Walthert, L., Blaser, P., Lüscher, P., Luster, J., \& Zimmermann, S. (2003). Langfristige Waldökosystem-Forschung LWF in der Schweiz. Kernprojekt Bodenmatrix. Ergebnisse der ersten Erhebung 1994-1999, Vol. 276 (p. 340). Zürich: Swiss Federal Institute of Technology (ETH). E-Collection, available from World Wide Web, http://e-collection. ethbib.ethz.ch/show?type=bericht\&nr=276

Walthert, L., Zimmermann, S., Blaser, P., Lüscher, P., \& Luster, J. (2006). Waldböden der Schweiz-Band 3: Regionen Mittelland und Voralpen (p. 500). Bern: Ott Verlag. 